\title{
MENINGKATKAN KETERAMPILAN PRODUKSI MEDIA PEMBELAJARAN BERBASIS LINGKUNGAN DALAM MENINGKATKAN KOMPETENSI PROFESIONAL
}

\author{
H. M. Nasirun ${ }^{1}{ }^{*}$, Yulidesni ${ }^{1)}$ \\ ${ }^{1}$ Program Studi Pendidikan Guru PAUD Universitas Bengkulu, Jalan W.R Supratman, Bengkulu, \\ Indonesia
}

Korespondensi Penulis. E-mail: h.m.nasirun@gmail.com, Telp : 081369306506

\begin{abstract}
Abstrak
Tujuan penelitian untuk meningkatkan keterampilan produksi media pembelajaran berbasis lingkungan guna meningkatkan kompetensi Profesional mahasiswa dalam Mata Kuliah Media Pembelajaran pada Program Studi S1 Pendidikan Guru PAUD FKIP Universitas Bengkulu. Jenis penelitian menggunakan Penelitian Tindakan Kelas. Sampel penelitian mahasiswa semester 3 pada Program Studi S1 Pendidikan Guru PAUD FKIP Universitas Bengkulu berjumlah 70 orang yang mengambil mata kuliah Media Pembelajaran.Teknik pengumpulan data menggunakan instrumen penilaian dan instrumen media pembelajaran untuk memperoleh data hasil produksi. Hasil penelitian menunjukkan peningkatan keterampilan produksi media pembelajaran berbasis lingkungan dalam kompetensi profesional pada mahasiswa S1 Pendidikan Guru PAUD FKIP Universitas Bengkulu. Disarankan untuk penelitian berikutnya agar melakukan penelitian secara berulang agar mahasiswa lebih bisa menghasilkan produksi media pembelajaran yang baik. Bagi penelitian berikut disarankan agar lebih fokus pada satu atau dua jenis media pada kedua siklus penelitian dan kajian keterkaitan aspek perkembangan dalam produksi media pembelajaran pada penelitian selanjutnya.
\end{abstract}

Kata kunci: Media pembelajaran, Berbasis Lingkungan, Kompetensi Profesional.

\section{IMPROVING ENVIRONMENT-BASED LEARNING MEDIA PRODUCTION SKILLS IN IMPROVING PROFESSIONAL COMPETENCY}

\begin{abstract}
The problems in this class action research are: Does Improve Media Production Skills in Environment-Based Learning can Increase Professional Competence in Undergraduate Students in PAUD Teacher Education FKIP Bengkulu University. The aim of the study was to improve the production skills of environment-based learning media in order to improve the professional competence of students in the Learning Media Course in the PAUD Teacher Education Study Program at the University of Bengkulu FKIP. This type of research uses Classroom Action Research. The research sample for the third-semester students in the PAUD Teacher Training Program at the University of Bengkulu FKIP was 70 people who took the course in Learning Media. Data collection techniques use assessment instruments and learning media instruments to obtain production data. The results of the study showed an increase in the skills of production of environment-based learning media in professional competency in undergraduate students of PAUD Teacher Education FKIP Bengkulu University. It is recommended for the next study to do research repeatedly so that students can better produce good learning media production. For the following research, it is recommended that more focus on one or two types of media in the two cycles of research and the study of the relationship of developmental aspects in the production of learning media in subsequent research.
\end{abstract}

Keywords: Learning media, Environmental Based, Professional Competence

\section{PENDAHULUAN}

Media merupakan komponen yang sangat penting dalam suatu proses komunikasi (Asyhar,
2012: 5). Menurut Barlo dalam Asyhar (2012: 5), proses komunikasi melibatkan paling kurang tiga komponen utama, yakni pengirim atau 
sumber pesan (source), perantara (media), dan penerima (receiver). Media memiliki peran penting, yaitu suatu sarana atau perangkat yang berfungsi sebagai perantara atau saluran dalam suatu proses komunikasi antara komunikator dan komunikan.

Pembelajaran diartikan sebagai proses interaktif antara guru dan siswa yang berlangsung secara dinamis. Pembelajaran menurut Degeng dalam Asyhar (2012:7) dimaksudkan sebagai upaya membelajarkan pembelajar (anak, siswa, peserta didik). Menurut Punaji dan Asyhar,pembelajaran juga dimaksudkan sebagai upaya yang dilakukan oleh pembelajar (guru, instruktur) dengan tujuan untuk membantu siswa agar bisa belajar dengan mudah.

Media pembelajaran menurut Gerlach \& Elly dalam Asyhar (2012:7) memiliki cakupan yang sangat luas yaitu: termasuk manusia, materi atau kajian yang membangun suatu kondisi yang membuat peserta didik mampu memperoleh pengetahuan, keterampilan atau sikap. Media pembelajaran mencakup semua sumber yang diperlukan untuk melakukan komunikasi dalam pembelajaran.

Media pembelajaran merupakan salah satu unsur penting dalam proses kegiatan pembelajaran. Media pembelajaran merupakan bagian dari komponen sistem instruksional (KSI) yaitukomponen-komponen yang harus ada dalam proses pembelajaran. Media pembelajaran sebagai bagian komponen sistem intruksional harus dikuasai oleh pendidik maupun calon pendidik.

Pendidik harus menguasai konsep-konsep atau teori media pembelajaran, pemilihan media pembelajaran, tehnik produksi media pembelajaran, dan sekaligus penerapannya dalam proses pembelajaran. Jadi demikian pentingnya peran media pembelajaran pada proses pembelajaran. Namun demikian belum semua pendidik atau guru menguasai dan terampil dalam produksi media pembelajaran.

Kenyataan di lapangan masih banyak pendidik atau guru yang kurang memahami dan kurang terampil dalam produksi media pembelajaran, sehingga para pendidik atau guru masih banyak yang tidak menggunakan media pembelajaranyang diproduksi sendiri dalam proses pembelajarannya. Pendidik atau guru lebih banyak melakukan pemilihan media pembelajaran yang sudah ada. Rendahnya kemampuan dalam produksi media pembelajaran memiliki konsekuensi banyak pendidik atau guru yang menggunakan media pengajaran "by utilization" atau media yang tinggal menggunakan saja.

Rendahnya kemampuan dan keterampilan memproduksi media pembelajaran bagi pendidik atau guru sebagai akibat dari rendahnya kemampuan mahasiswa dalam memproduksi media pembelajaran.

Proses belajar mengajar di lembaga pendidikan PAUD media pembelajaran memiliki peran sangat penting dalam keberhasilan proses pembelajarannya. Untuk itu, pendidik atau guruPAUD dituntut memiliki kemampuan dan keterampilan produksi media pembelajaran. Hal tersebut juga dimaksudkan agar pendidik atau guru/calon pendidik agar tidak tergantung pada media pengajaran sudah jadi.

Pada pelaksanaan perkuliahan mata kuliah, media pembelajaran memiliki peran penting dan strategis serta sangat diperlukan bagi mahasiswa S1Pendidikan Guru PAUD. Mata kuliah Media pembelajaran bertujuan membekali konsep-konsep teori dan keterampilan produksi media pembelajaran. Oleh karena itu, pendidik atau guru/calon guru pada lemabaga pendidikan PAUD harus menguasai dan mampu memproduksi media pembelajaran yang diperlukan untuk menunjang kompetensinya.

Media Pembelajaran merupakan mata kuliah yang bertujuan mempersiapkan calon pendidik atau calon guru PAUD menguasai dan terampil dalam produksi media pembelajaran.Jadi keahlian dan keterampilan guru dalam produksi media pembelajaran yang diajarkan melalui mata kuliah media pembelajaran merupakan mata kuliah yang mendasar untuk membentuk calon pendidik atau calon guru PAUD yang profesional.

Secara garis besar ruang lingkup mata kuliah media pembelajaran pada program S1 Pendidikan Guru PAUD diantaranya: (1) Kedudukan dan konsep media pembelajaran; (2) Media pembelajaran bagian komponen sistem instruksional (KSI); (3) Berbagai jenis media pembelajaran; (4) Kelebihan dan kelemahan media pembelajaran; (4) Penggolongan media menurut berbagai sudut pandang; (5) Cara-cara pemilihan media pembelajaran; (6) Desain produksi media pembelajaran; (7) Produksi media pembelajaran; (8) presentasi hasil 
produksi media pembelajaran dalam bentuk pembelajaran.

Pembelajaran pada pendidikan anak usia dini memiliki prinsip-prinsip belajar sesuai dengan perkembangan anak, diantaranya prinsip pemanfaatan lingkungan yang paling dekat dengan anak. Oleh karena itu, dalam produksi media yang akan diterapkan dalam penelitian ini adalah termasuk pemanfaatan lingkungan sebagai bahan-bahan untuk produksi media tersebut (Kurikulum Prodi S1 Pendidikan Guru PAUD; 2013)

Sebagaimana dalam prinsip belajar pada Pendidikan Anak Usia Dini, yaitu: prinsip pemanfaatan lingkungan yang paling dekat dengan anak, maka dalam produksi media pembelajaran dengan memanfaatkan bahanbahan dari lingkungan yang terdekat dengan anak.

Bahan-bahan dari lingkungan dimaksud bisa terdiri dari barang-barang bekas ataupun sumber daya alam (tanah liat, batu-batuan) dari lingkungan terdekat dengan anak. Luasnya kajian media pembelajaran dan terbatasnya waktu perkuliahan, khususnya dalam produksi media pembelajaran menjadi perhatian khusus peneliti.

Adanya penelitian ini diharapkan memberi kesempatan mahasiswa untuk melakukan praktek produksi media pembelajaran yang didasarkan pada bahanbahan lingkungan dan sekaligus dapat mengaplikasikan dalam berbagai pendekatan pembelajaran.

Adanya penerapan praktik produksi media pembelajaran di kelas tersebut diharapkan dapat membekali lulusan program studi S1 Pendidikan Guru PAUD FKIP Universitas Bengkulu kemampuan dalam memproduksi media pembelajaran yang nantinya sebagai bekal mengajar dan akan meningkatkan kompetensinya.

Secara umum permasalahan yang akan dipecahkan dalam penelitian ini: Apakah dengan Meningkatkan Keterampilan Produksi Media Pembelajaran Berbasis Lingkungan dapat Meningkatkan Kompetensi Profesional padaMahasiswa S1 Pendidikan Guru PAUD FKIP Universitas Bengkulu.

Pemecahan masalah yang akan dilakukan dalam penelitian ini: menggunakan Penelitian Tindakan Kelas(PTK), yang akan dilakukan melalui dua siklus. Penelitian tindakan kelas ini melibatkan mahasiswa semester III Program
Studi S1 Pendidikan Guru PAUD FKIP Universitas Bengkulu.

Secara umum tujuan penelitian ini untuk meningkatkan keterampilan produksi media pembelajaran berbasis lingkungan guna meningkatkan kompetensi profesional mahasiswa dalam Mata Kuliah Media Pembelajaran pada Program Studi S1 Pendidikan Guru PAUD FKIP Universitas Bengkulu

Ruang lingkup penelitian ini termasuk dalam ruang lingkup bidang proses belajar mengajar yaitu komponen media pendidikan dalam mata kuliah Media Pembelajaran pada program S1 Pendidikan Anak Usia Dini. Mata Kuliah MediaPembelajaran pada Program Pendidikan Guru PAUD, diantaranya membahas pengertian, tujuan, fungsi media pembelajaran, kelebihan dan kelemahan, klasifikasi dan produksi media pembelajaran. Dalam Penelitian ini fokus penelitian pada produksi media pembelajaran yang berkaitan dengan aspek perkembangan kognitif maupun bahasa anak usia dini.

\section{METODE}

Penelitian yang akan dilakukan ini menggunakan metode dan jenis penelitian tindakan kelas. Penelitian tindakan kelas menurut Suharjono dalam Asrori, dkk (2009; 18), memiliki tujuan: (1) dapat meningkatkan mutu atau kualitas pembelajaran, isi atau materi pembelajaran, masukan-masukan dalam rangka perbaikan pembelajaran, proses pembelajaran, serta hasil pendidikan dan pembelajaran; (2) dapat membantu guru atau tenaga kependidikan lainnya untuk mengatasi masalah-masalah dalam pembelajan di kelas; (3) dapat meningkatkan sikap profesional pendidik/guru maupun tenaga kependidikan lainnya; (4) menumbuh-kembangkan budaya akademik untuk memperbaiki kualitas pembelajaran.

Arikunto (2012:3) mengungkapkan penelitian tindakan kelas merupakan suatu pencermatan terhadap kegiatan belajar berupa sebuah tindakan, yang sengaja dimunculkan dan terjadi dalam sebuah kelas secara bersama. Sedangkan menurut Purwadi dalam Sukidin, dkk (2010:10), penelitian tindakan kelas adalah suatu bentuk penelitian yang dilaksanakan oleh guru untuk memecahkan masalah yang dihadapi dalam melaksanakan tugas pokoknya, yaitu mengelola pelaksanaan Kegiatan Belajar Mengajar (KBM) dalam arti luas. 
Produksi media melalui penelitian tindakan kelas ini akan digunakan bahan-bahan dari lingkungan, diantaranya: berupa bahanbahan alam (misal tanah liat, air, api dsb); macam-macam jenis tanaman (daun; biji-bijian; buah-buahan dsb); jenis barang-barang bekas (koran, bekas tempat minuman, pipet dsb).

Luaran penelitian tindakan kelas dapat mencakup; (1) Perbaikan dan peningkatan kualitas kinerja siswa; (2) Perbaikan dan peningkatan kualitas proses pembelajaran; (3) Perbaikan dan peningkatan kualitas produksi media pembelajaran; dan (4) Perbaikan dan peningkatan kualitas alat evaluasi.

Penelitian Tindakan Kelas (PTK) ini dilaksanakan melalui dua tahapan, yaitu: tahapan mendesaign atau merancang media pembelajaran dan tahapan produksi media pembelajaran sesuai dengan rancangannya. Penelitian Tindakan Kelas (PTK) dilaksanakan melalui dua siklus yaitu: siklus pertama produksi media pembelajaran dari bahan bijibjian dan tanah liat aspek perkembangan kognitif /berhitung dan siklus kedua produksi media pembelajaran dari barang bekas dan batubatuan aspek perkembangan bahasa

\section{HASIL DAN PEMBAHASAN}

Asosiasi Teknologi dan Komunikasi Pendidikan (Association of Education and Communication Technology/AECT) dalan Sadiman, dkk (1984:6) menyebutkan Media adalah Segala bentuk dan saluran yang digunakan orang untuk menyalurkan pesan/informasi. Sementara Menurut Gagne dalam Sadiman, dkk (1984:6) Media adalah berbagai jenis komponen dalam lingkungan siswa yang dapat merangsang untuk belajar. Jadi Media pembelajaran adalah berbagai jenis komponen dalam proses belajar mengajar.

Media pembelajaran dapat dipahami sebagai "segala sesuatu yang dapat menyampaikan atau menyalurkan pesan dari suatu sumber secara terencana, sehingga terjadi lingkungan belajar yang kondusif dimana penerimanya dapat melakukan proses belajar secara efisien dan efektif (Asyhar; 2012:8).

Media pembelajaran merupakan bagian dari sistem instruksional yang tidak dapat dipisahkan dengan kemampuan profesional guru. Komponen Sistem Instruksional (KSI) yang terdiri dari komponen tujuan, komponen materi, komponen evaluasi, komponen media dan sumber belajar, serta komponen guru sangat menentukan keberhasilan proses pembelajaran di kelas.

Media pembelajaran bagi pelaksanaan pembelajaran di PAUD memiliki makna dan kedudukan yang sangat penting, sebab dengan adanya media terutama melalui lembar kerja anak (LKA) dapat menciptakan pembelajaran menjadi lebih interaktif dan hidup, lebih menarik dan tidak membosankan, anak menjadi aktif, kreatif, dan mudah memahami apa yang dikerjakan dan dipelajarinya (Arsyad, 2005: 2123).

Sadiman, dkk (1984:17-18) mengungkapkan media pembelajaran sangat berguna untuk; (1) memperjelas penyajian pesan agar tidak terlalu bersifat verbalistis (dalam bentuk kata-kata tertulis atau lisan belaka); (2) mengatasi keterbatasan ruang, waktu dan daya indra;(3) penggunaan media pendidikan secara tepat dan bervariasi dapat mengatasi sifat pasif anak didik; (4) dengan sifat yang unik pada tiap siswa ditambah lagi dengan lingkungan dan pengalaman yang berbeda, sedangkan kurikulum dan materi pendidikan ditentukan sama untuk setiap siswa, maka guru banyak mengalami kesulitan bilamana semuanya itu harus diatasi sendiri. Hal ini akan lebih sulit bila latar belakang lingkungan guru dengan siswa juga berbeda.

Masalah ini dapat diatasi dengan media pendidikan, yaitu dengan kemampuannya dalam: (a) memberikan perangsang yang sama; (b) mempersamakan pengalaman; (c) menimbulkan persepsi yang sama.

Fungsi media pembelajaran selain dikemukakan di atas, menurut Levie \& Lenz (1982) dalam Arsyad (2005: 16-17), ada empat fungsi media pembelajaran (khusus media visual) diantaranya (1) fungsi atenti, (2) fungsi afektif, (3) fungsi kognitif, dan (4) fungsi kompensatoris, Sedangkan menurut Ibrahim (1987; 12-16), (1) fungsi media mengatasi hambatan-hambatan belajar (verbalisme, salah tafsir, perhatian tidak terpusat, tidak terjadi pembentukan tanggapan, dan keadaan fisik lingkungan yang mengganggu); (2) dari segi siswa (meningkatkan motivasi, meningkatkan pengamatan, memudahkan pemahaman, memungkinkan siswa mengetahui hal-hal yang sulit atau tidak mudah terlihat, dsb), (3) bagi guru dapat memudahkan mengajar dengan waktu yang lebih singkat.

Guru dalam setiap melaksanakan kegiatan pembelajaran di kelas dituntut untuk 
menggunakan media pembelajaran, baik melalui proses pemilihan media pembelajaran maupun mendesain sendiri media tersebut ketika tidak adanya media pembelajaran di sekolah.

Kompetensi profesional guru di peroleh dari saat kuliah melalui pendalaman berbagai mata kuliah yang tergabung dalam MKBM (Strategi pembelajaran; Evaluasi pembelajaran; Media pembelajaran), maupun dalam mata kuliah inti, serta mata kuliah penunjang lainnya. Salah satu mata kuliah yang mendasar dan berkaitan dengan pembentukan profesionalisme guru dalam melaksanakan proses belajar mengajar di kelas sebagaimana disebutkan di atas adalah mata kuliah media pembelajaran. Mata kuliah media pembelajaran bertujuan membekali mahasiswa tentang kemampuan untuk memahami konsep media pengajaran, prinsip-prinsip penggunaan dan pemilihan media pengajaran maupun kemampuan memproduksi media pembelajaran.

Proses pembelajaran pada pendidikan anak usia dini adalah berbeda dengan proses pembelajaran pada tingkatan pendidikan lainnya. Peran media pembelajaran sangat penting dan dituntut untuk selalu siap, sebab tanpa kesiapan media pembelajaran proses belajar di PAUD tidak akan berjalan dengan optimal. Media pembelajaran yang digunakan pada program PAUD harus sesuai dengan prinsip pembelajaran di PAUD. Prinsip pembelajaran pada anak usia dini adalah bermain sambil belajar atau belajar melelui bermain. Selain hal tersebut, belajar pada pendidikan anak usia dini dimulai dari yang sederhana dan mudah menuju yang kompleks, dari yang konkrit menuju yang abstrak, dimulai dari lingkungan dekat anat menuju yang jauh.

Hartati (2007, 44-46) mengungkapkan pembelajaran pada pendidikan anak usia dini menganut prinsip berangkat dari yang di miliki anak; belajar harus menantang pemahaman anak; dan belajar dilakukan sambil bermain. Belajar pada pendidikan Anak usia dini bukan datang dari orang-orang disekitarnya (didekte) tetapi dimulai dari apa yang dimiliki anak itu sendiri. Belajar harus membuat anak untuk selalu mencoba dan berusaha untuk bisa melakukannya (menantang). Belajar dilakukan anak melalui berbagai permainan yang dilakukan oleh anak.

Media pembelajaran menciptakan pembelajaran menjadi aktif, sebab pembelajaran dapat melibatkan mental maupun fisik anak..
Selain hal tersebut belajar aktif dapat diciptakan melalui berbagai hal, diantaranya:: pembelajaran diarahkan pada suatu objek; (2) adanya refleksi pada kegiatan; (3) melibatkan motivasi instrinsik, penemuan dan menyimpulkan; (4) belajar pemecahan masalah. Selain itu belajar aktif memiliki indikator: (1) prakarsa kegiatan timbul dari minat dan keinginan anak; (2) anak-anak memilih bahan dan memutuskan apa yang dikerjakan; (3) anakanak mengekspresikan bahan secara aktif dengan seluruh inderanya; (4) anak menentukan hubungan sebab akibat melalui pengalaman langsung objek; (5) anak mentransformasi dan menggabungkan bahan-bahan; (6) anak menggunakan alat dan perlengkapan yang sesuai dengan usianya; (7) anak menggunakan alat kasarnya; (8) anak menceritakan pengalamannya; (9) anak berkata tentang apa yang mereka lakukan dengan kata-katanya sendiri (Masitoh, dkk; 2005: 78-89).

Kemampuan guru memproduksi media pembelajaran tersebut, merupakan salah satu tuntutan kompetensi profesional guru. Sebagaimana disebutkan dalam Peraturan Pemerintah No. 19 Tahun 2005, tentang Standar Nasional Pendidikan, pasal 28 ayat C menyatakan: bahwa seorang pendidik atau guru harus memiliki dan menguasai kompetensikompetensi yang di persyaratkan sebagai seorang guru. Salah satu kompetensi yang berkaitan dengan tugas utama seorang guru adalah kompetensi profesional.

Kompetensi profesional yang dimiliki seorang guru akan menentukan keberhasilan guru dalam menjalankan tugas utamanya yaitu melakukan pengajaran di dalam kelas. Salah satu bagian dari kompetensi profesional guru adalah kemampuan dalam memproduksi media pembelajaran. Kemampuan dalam merancang dan memproduksi media pembelajaran sangat memiliki peran penting bagi seorang pendidik/guru maupun calon pendidik/guru. Mengajar tanpa menggunakan media pembelajaran akan mengakibatkan kurang efektifnya proses belajar mengajar dan sekaligus kurang optimalnya hasil belajar siswa. Proses pembelajaran di lembaga pendidikan anak usia dini demikian penting dan strategis bagi pengembangan aspek-aspek perkembangan anak.

Produksi media pembelajaran menggunakan teknis kerja kelompok, teknik ini dipergunakan agar mahasiswa bisa saling 
bekerjasama dan saling membantu dalam mengerjakan tugas-tugas produksi media tersebut.Kerja kelompok memudahkan dan meringankan penyelesaian pekerjaan dalam produksi media, selain itu dapat mempersingkat waktu penyelesaian dan diharapkan hasil produksi yang optimal.

Media pembelajaran yang diproduksi disesuaikan dengan tema dan sub tema pembelajaran yang akan dilakukan. Selanjutnya hasil produksi media pembelajaran nantinya akan digunakan sebagai media dalam praktek pembelajaran yang dilakukan secara klasikal. Menurut Sadiman dalam Asyhar (2012: 99-110), menyebutkan proses produksi media meliputi beberapa tahapan, sebagai berikut: (1) tahap identifikasi kebutuhan; (2) tahap perumusan tujuan; (3) perumusan kriteria keberhasilan; (4) Penulisan naskah media pengajaran; (5) tahap uji coba; (6) tahap evisi jika ada, jika tidak dilanjutkan (7) tahap produksi.

Selanjutnya menurut Ibrahim $(1987 ; 109$ 113) mengemukakan langkah-langkah dalam mendesain (produksi) media pembelajaran, diantaranya: (1) menemukan ide, (2) merumuskan tujuan, (3) menentukan karakteristik audiens, (4) merumuskan kerangka isi bahan, (5) menentukan jenis media (6) menentukan treatment dan partisipasi siswa, (7) membuat story board, (8) menentukan bahan, (9) pelaksanaan produksi, (10) penyuntingan dan uji coba.

Sudjana dan Rivai (2002: 208) menyatakan guru dan siswa bisa mempelajari keadaan sebenarnya di luar kelas (lingkungan) yang aktual sebagai sumber dan media pembelajaran untuk menunjang proses pembelajaran. Disebutkan banyak keuntungan yang diperoleh dari kegiatan pemanfaatan lingkungan dalam proses pembelajaran, diantaranya: (1) Lebih menarik dan menumbuhkan motivasi; (2) Belajar lebih bermakna karena sesuai keadaan sebenarnya; (3) Bahan belajar lebih faktual; (4) Sumber dan media belajar lebih variatif; (5) Kegiatan belajar lebih komprehensif; (6) Siswa dapat menghayati aspek-aspek kehidupan yang ada dilingkungannya.

Setelah melalui proses pengolahan data dari penilaian rancangan media pembelajaran dari masing-masing kelompok pada kelas A dan kelas B pada siklus pertama, maka dalam sajian penelitian ini dapat disajikan hasil penelitian melalui rekapitulasi penilaian rancangan media pembelajaran bahan biji-bijian dan tanah liat pada klas A dan klas B dapat dilihat pada Tabel 1 berikut:

Tabel 1. Rekapitulasi Penilaian Rancangan Media Pembelajaran Bahan Biji-Bijian Dan Tanah Liat Kelas A Dan B (Siklus 1)

\begin{tabular}{cccc}
\hline Aspek & $\begin{array}{c}\text { Bahan } \\
\text { Biji-bijian }\end{array}$ & $\begin{array}{c}\text { Bahan } \\
\text { Tanah Liat }\end{array}$ & $\begin{array}{c}\text { Rata- } \\
\text { Rata }\end{array}$ \\
1 & 3,35 & 3,00 & 3,175 \\
2 & 3,725 & 3,75 & 3,735 \\
3 & 3,185 & 3,63 & 3,723 \\
4 & 3,94 & 4,00 & 3,97 \\
5 & 4,00 & 4,00 & 4,00 \\
6 & 3,19 & 3,13 & 3,16 \\
7 & 3,475 & 3,13 & 3,03 \\
8 & 3,875 & 3,75 & 3,813 \\
9 & 3,875 & 3,88 & 3,878 \\
10 & 3,74 & 3,50 & 3,62 \\
Rata- & 3,70 & 3,565 & 3,635 \\
Rata & & & \\
\hline
\end{tabular}

Setelah dilakukan pengolahan data yang didasarkan pada penilaian rancangan media pembelajaran akhirnya dapat disajikan dalam bentuk tabel di atas. Berdasarkan Tabel 1 tersebut dapat ditarik kesimpulan bahwa: Rancangan media pembelajaran yang disusun oleh masing-masing kelompok pada klas A dan B secara umum dalam 10 aspek dalam kategori baik,dengan rata-rata $(3,635)$.

Kategori tersebut menunjukkan bahwa pemahaman dalam membuat rancangan media pembelajaran oleh mahasiswa sudah baik dan tindak lanjut berikutnya adalah pelaksanaan produksi media pembelajaran sesuai dengan rancangan media pembelajaran yang telahdibuat oleh kelompok klas A dan B tersebut.

Berdasarkan sajian Tabel 2 berikut diperoleh hasil produksi media pembelajaran siklus 1 kelompok pada klas A dan B dari bahan biji-bijian dan tanah liat berada pada kategori cukup (nilai rata-rata:3,36). Apabila dilihat dari unsur-unsur dalam penelitian, maka pada produksi bahan biji-bijian unsur kerapian dan pewarnaan kategori baik, sementara dalam produksi media pembelajaran dari bahan tanah liat unsur pewarnaan dalam kategori baik. Unsur-unsur seni, kerapian dan kehalusan baik pada produksi media pembelajaran bahan bijibijian dan tanah liat kategori cukup. 
Tabel 2. Rekapitulasi Penilaian Rancangan Media Pembelajaran Bahan Biji-Bijian Dan Tanah Liat Kelas A Dan B (Siklus 1)

\begin{tabular}{lccc}
\hline Bahan/Unsur & Kelas A & Kelas B & $\begin{array}{c}\text { Rata- } \\
\text { Rata }\end{array}$ \\
$\quad$ Biji-bijian & & & \\
Seni & 3,13 & 3,71 & 3,42 \\
Kerapian & 3,25 & 3,86 & 3,56 \\
Kahalusan & 3,00 & 3,00 & 3,00 \\
Pewarnaan & 3,25 & 4,00 & 3,63 \\
$\quad$ Rata-rata & 3,16 & 3,64 & 3,40 \\
$\quad$ Tanah Liat & & & \\
Seni & 3,25 & 3,00 & 3,13 \\
Kerapian & 3,50 & 3,29 & 3,40 \\
Kahalusan & 3,00 & 3,00 & 3,00 \\
Pewarnaan & 3,88 & 3,57 & 3,73 \\
$\quad$ Rata-rata & 3,41 & 3,22 & 3,32 \\
Rata-rata total & 3,29 & 3,43 & 3,36 \\
\hline
\end{tabular}

Hasil penelitian tindakan kelas (PTK) siklus pertama baik rancangan media pembelajaran dan hasil produksi media pembelajaran dapat disimpulkan bahwa secara umum rancangan media pembelajaran ada pada kategori baik, namun pada hasil produksi media pembelajaran secara umum ada pada kategori cukup. Hasil tersebut belum menunjukkan pada kriteria atau kategori yang sama, artinya pada hasil produksi media pembelajaran belum berada pada kriteria baik. Sebagai refleksi perlu ada perbaikan-perbaikan dalam produksi media pembelajaran. Langkah perbaikan yang dilakukan adalah dalam pengerjaan produksi media pembelajaran perlu ditingkatkan ketelitian dan keberhati-hatian dalam pengerjaannya. Penggunaan cat pewarna harus dipilih yang lebih cerah sesuai warna kesenangan anak-anak.

Hasil siklus kedua, setelah melalui proses pengolahan data dari penilaian rancangan media pembelajaran dari masing-masing kelompok pada kelas A dan kelas B pada siklus kedua, maka dapat disajikan hasil penelitian melalui rekapitulasi penilaian rancangan media pembelajaran bahan barang bekas dan batubatuan kelas A dan kelas B dapat dilihat pada Tabel 3.
Tabel 3. Rekapitulasi Penilaian Rancangan Media Pembelajaran Bahan Barang Bekas Dan Batu-Batuan Kelas A Dan B (Siklus 2)

\begin{tabular}{cccc}
\hline Aspek & $\begin{array}{c}\text { Bahan } \\
\text { Barang } \\
\text { bekas }\end{array}$ & $\begin{array}{c}\text { Bahan } \\
\text { Batu- } \\
\text { batuan }\end{array}$ & $\begin{array}{c}\text { Rata- } \\
\text { Rata }\end{array}$ \\
1 & 3,07 & 3,22 & 3,15 \\
2 & 3,57 & 3,46 & 3,52 \\
3 & 4,00 & 3,63 & 3,82 \\
4 & 4,00 & 3,88 & 3,94 \\
5 & 4,00 & 3,94 & 3,97 \\
6 & 3,00 & 3,00 & 3,00 \\
7 & 3,30 & 3,18 & 3,24 \\
8 & 3,75 & 4,00 & 3,88 \\
9 & 4,00 & 3,75 & 3,88 \\
10 & 4,02 & 3,82 & 3,92 \\
Rata- & 3,27 & 3,59 & 3,63 \\
Rata & 3,27 \\
\hline
\end{tabular}

Berdasarkan tabel tersebut dapat ditarik kesimpulan bahwa: Rancangan media pembelajaran yang disusun oleh masing-masing kelompok pada klas A dan B secara umum dalam 10 aspek dalam kategori baik, dengan rata-rata $(3,63)$. Kategori tersebut menunjukkan bahwa pemahaman dalam membuat rancangan media pembelajaran oleh mahasiswa sudah baik dan tindak lanjut berikutnya adalah pelaksanaan produksi media pembelajaran sesuai dengan rancangan media pembelajaran yang telah dibuat oleh masing-masing kelompok pada klas A dan B tersebut.

Tabel 4. Rekapitulasi Penilaian Rancangan Media Pembelajaran Bahan Barang Bekas Dan Batu-Batuan Klas A Dan B (Siklus 2)

\begin{tabular}{lccc}
\hline Bahan/Unsur & Kelas A & Kelas B & $\begin{array}{c}\text { Rata- } \\
\text { Rata }\end{array}$ \\
Barang Bekas & & & \\
Seni & 2,88 & 3,43 & 3,16 \\
Kerapian & 3,25 & 3,57 & 3,41 \\
Kahalusan & 3,00 & 3,29 & 3,15 \\
Pewarnaan & 3,25 & 3,71 & 3,48 \\
$\quad$ Rata-rata & 3,21 & 3,50 & 3,36 \\
$\quad$ Batu-Batuan & & & \\
Seni & 3,25 & 3,00 & 3,13 \\
Kerapian & 3,13 & 3,43 & 3,26 \\
Kahalusan & 2,88 & 3,00 & 2,94 \\
Pewarnaan & 2,88 & 2,86 & 2,92 \\
$\quad$ Rata-rata & 3,00 & 3,10 & 3,05 \\
Rata-rata total & 3,25 & 3,30 & 3,23 \\
\hline
\end{tabular}


Berdasarkan sajian tabel di atas hasil produksi media pembelajaran siklus 2 pada klas A dan B dari bahan barang bekas dan batubatuan berada pada kategori cukup dengan nilai rata-rata $(3,23)$. Apabila dilihat dari unsur-unsur dalam penelitian, maka pada produksi bahan barang bekasdan dari bahan batu-batuansemua unsur dalam penelitian kategori cukup

\section{SIMPULAN DAN SARAN}

\section{Simpulan}

Hasil penelitian tindakan kelas (PTK) siklus pertama baik rancangan media pembelajaran dan hasil produksi media pembelajaran dapat disimpulkan bahwa secara umum rancangan media pembelajaran ada pada kategori baik, sedangkan pada hasil produksi media pembelajaran pada siklus pertama dan kedua secara umum ada pada kategori cukup.

Berdasarkan pada sajian hasil penelitian pada siklus 1 dan siklus 2 dan analisis data serta hasil analisis data tersebut di atas, selanutnya dalam pembahasan ini dibahas temuan-temuan penelitian yang ada, yaitu:

Hasil penelitian pada siklus 1 dan siklus 2 menunjukkan bahwa hasil desain atau rancangan media pembelajaran dalam penelitian kategori baik, walaupun tidak mengalami peningkatan. Menunjuk pada hasil tersebut bahwa dalam mendesain atau merancang media pembelajaran sudah cukup baik bila dibandingkan sebelum dilaksanakan penelitian tindakan kelas ini. Pada aspek-aspek tertentu masih menjadi titik lemah dalam mendesain mmedia pembelajaran ini, misalnya pada penentuan ide atau tema; dalam merumuskan tujuan yang mengandung rumusan ABCD (Audiens, Behavior, Condition dan degree) masih menjadi kekurangan dalam merumuskannya; selanjutnya dalam menerapkan treatment atau perlakuan pada anak atas penggunaan media yang akan diproduksi juga masih kurang; dan terakhir dalam membuat sketsa atau story board juga masih menjadi kendala.

Pada hasil produksi media yang mengalami kendala adalah bentuk atau model media pembelajaran dari bahan-bahan berbasis lingkungan kurang dapat sesuai dan ada keterkaitan dengan aspek perkembangan yang akan diproduksi medianya. Sebagai contoh bahan lingkungan dari batu-batuan akan digunakan membuat media menyangkut aspek perkembangan bahasa. Peiihan barang-barang bekas untuk diproduksi media pembelajaran menyangkut aspek perkebangan bahasa lebih sulit bila untuk mengembangkan aspek perkembangan motorik halus anak.

Penggunaan bahan biji-bijian lebih baik dan sangat mudah dikaitkan dengan aspk perkembangan kogntif dalam berhitung, namun untuk bahan tanah liat juga mengalami kendala dan kesulitan untuk membuat media terkait aspek kognitif dalam berhitung

\section{Saran}

Penelitian tindakan kelas ini, hendaknya memberi perhatian dan fokus dalam menentukan unsur ide atau tema, unsur treatment atau perlakuan pada anak serta unsur story board atau membuat sketsa rancangan media pembelajaran yang akan diproduksi. Dalam penentuan bahan juga mengalami kesulitan dalam kaitannya dengan aspek perkembangan tersebut.

Dalam produksi media melalui bahan lingkungan hendaknya tidak variatif dalam jenis medianya pada setiap siklus, pada kenyataanya bila jenis media pembelajaran tidak sama dalam siklus 1 dan siklus 2 akan mengalami kendala tersendiri dan pada akhirnya kurang mengalami peningkatan yang berarti dari setiap siklusnya.

Sebagai kesimpulan dan tindak lanjut hendaknya penelitan sejenis dilakukan berulangulang dengan jenis media dengan bahan yang sejenis pada setiap siklusnya, sehingga dapat mendukung calon-calon guru yang memiliki kopetensi profesional kedepannya.

\section{DAFTAR PUSTAKA}

Aqib, Zainal, dkk. 2009. Penelitian Tindakan Kelas. Bandung: Yrama Widya.

Arikunto, Suharsimi. 2012. Prosedur Penelitian Suatu Pendekatan Praktik Edisi (Revisii VI). Jakarta: Rineka Cipta.

Arsyad, Azhar. 2005. Media Pembelajaran. Jakarta: Raja Grafindo Persada

Asyhar; H. Rayandra. 2012. Kreatif Mengembangkan Media Pembelajaran. Jakarta: Referensi

Asrori, Mansyur dan Harun Rasyid. 2009. Penelitian Tindakan Kelas, Peningkatan Kompetensi profesional Guru. Yogyakarta: Multi Press.

Departemen Pendidikan Nasional; Dirjen Pendidikan Dasar dan Menengah. 2006. Pedoman Penerapan Pendekatan "Beyond Center and Circle Time 
Jurnal Smart PAUD, Vol. 2, No. 1, Januari 2019

H.M. Nasirun \& Yulidesni

(BCCT) (Pendekatan Sentra dan Lingkaran) Dalam Pendidikan Anak

Usia Dini, Jakarta

Hartati, Sofia. 2009. How To Be a Good Teacher and To Be a Good Mother. Jakarta: Enno Media.

Ibrahim. 1987. Media Instruksional (Arti, Fungsi, Pemilihan, Penggunaan dan Desain Pembuatan Media Sederhana) Malang: Jur.Kurtek IKIP Malang

Kurikulum Program Studi S1 Pendidikan Guru PAUD 2013, Silabus dan SAP Mata Kuliah Media Pengajaran. FKIP UNIB

Peraturan Pemerintah No.19.tentang Standar Nasional Pendidikan, Jakarta.

Sadiman, Arief S. Rahardjo; Anung Haryono, Raharjito. 1984. Media Pendidikan, Pengertian, Pengembangan dan Pemanfaatannya. Jakart: PT Raja Grafindo Persada

Sudjana, Nana dan Rivai, Ahmad. 2002. Media Pengajaran. Bandung: Sinar Baru Algensindo 